Check for updates

Cite this: RSC Adv., 2019, 9, 12291

Received 21st February 2019

Accepted 12th April 2019

DOI: 10.1039/c9ra01279f

rsc.li/rsc-advances

\section{Adamantyl and homoadamantyl derivatives from Garcinia multiflora fruits $\dagger$}

\author{
Yu Chen, $\ddagger^{\mathrm{a}}$ Ziyu Ma,,$^{\mathrm{a}}$ Haida Teng, ${ }^{\mathrm{a}}$ Fei Gan, ${ }^{\mathrm{a}}$ Hui Xiong, ${ }^{\mathrm{b}}$ Zhinan Mei*b \\ and Guangzhong Yang $(D * b c$
}

Nine undescribed caged polycyclic polyprenylated acylphloroglucinols (PPAPs), including adamantane type PPAPs (1-2), and homoadamantane type PPAPs (3-9), were isolated from the fruits of Garcinia multiflora, along with three known analogues. A new epimeric pair of isohypersampsonone B (5) and epiisohypersampsonone B (6), featuring an unusual hexahydrofuro[2,3-b]furan-diepoxy ring system fused in a homoadamantane skeleton, was not separated due to the rapid equilibration between the two isomeric forms. All new caged PPAPs (1-9), sharing a common isogeranyl group, were determined on the basis of comprehensive NMR and MS spectroscopic data. Their cytotoxicity against three human tumor cell lines (SGC-7901, HepG2, HCT-116) and the nitric oxide production inhibitory activity of lipopolysaccharides-stimulated RAW 264.7 cells were tested. Compounds 8 and 12 displayed mild cytotoxicity against three human cancer cell lines with $I_{50}$ values of 10-20 $\mu \mathrm{M}$. Furthermore, compounds 8 and 12 also exhibited NO production inhibitory effect with an $I C_{50}$ value of 18.24 and $12.50 \mu \mathrm{M}$ respectively.

\section{Introduction}

Fruits, fruit rinds, flowers, leaves, barks and stems originating from the genus Garcinia plant have been used as traditional medicine. ${ }^{1}$ They have received considerable attention from the scientific community for their powerful capacities to produce structurally fascinating and pharmacologically active polycyclic polyprenylated acylphloroglucinols (PPAPs), such as garcinol, ${ }^{2}$ xanthochymol, ${ }^{3}$ isoxanthochymol, ${ }^{3}$ cycloxanthochymol, ${ }^{3}$ etc. PPAPs with highly oxygenated acylphloroglucinol-derived cores are substituted with one or more prenyl or geranyl side chains. Up to now, more than 400 PPAPs have been isolated from nature, of which the majority are bicyclic polyprenylated acylphloroglucinols (BPAPs) with a bicyclo[3.3.1]nonane-2,4,9trione core. Caged PPAPs are a subclass of PPAPs containing the adamantane and homoadamantane skeleton, most of which are isolated from Hypericum species, especially from H. sampsonii. However, caged PPAPs are rarely reported from Garcinia plants. ${ }^{4}$ Garcinia multiflora Champ. is a traditional Zhuang

\footnotetext{
${ }^{a}$ College of Chemistry and Material Sciences, South-Central University for Nationalities, Wuhan 430074, P. R. China

${ }^{b}$ School of Pharmaceutical Sciences, South-Central University for Nationalities, Wuhan 430074, P. R. China. E-mail: meizhinan@163.com; yanggz888@126.com; Fax: +86 27 6784 1196; Tel: +862767841196

${ }^{c}$ National Demonstration Center for Experimental Ethnopharmacology Education (South-Central University for Nationalities), Wuhan 430074, P. R. China

$\dagger$ Electronic supplementary information (ESI) available. See DOI: 10.1039/c9ra01279f

\$ These authors contributed equally to this work.
}

medicine widely distributed in the south of China. Its fruits are edible consisting of vitamins, proteins, and minerals, but may also provide pharmacologically active compounds. ${ }^{5}$ Previous phytochemical investigations on the fruits led to isolation of seven new PPAPs with anti-inflammatory activity, including two caged PPAPs garcimultiflorone D and G. ${ }^{6-8}$

Taken together, these results prompted us to investigate the isolation of further caged PPAPs form G. multiflora and evaluate their biological activities. As a result, nine undescribed caged polycyclic polyprenylated acylphloroglucinols (PPAPs), including adamantane type PPAPs (1-2) and homoadamantane type PPAPs (3-9) were isolated from the fruits of $G$. multiflora, along with three known analogues. Herein, we report the isolation, structural elucidation, and biological activities of these isolated compounds.

\section{Result and discussion}

\subsection{Structural elucidation of isolated compounds}

Compound 1 was isolated as colorless, amorphous powder. Its molecular formula was determined to be $\mathrm{C}_{38} \mathrm{H}_{48} \mathrm{O}_{5}$ on the basis of the negative HR-ESI-MS ion at $m / z 583.34296[\mathrm{M}-\mathrm{H}]^{-}$(calcd 583.34290). The ${ }^{1} \mathrm{H}$ NMR spectrum of 1 revealed the presence of an unsubstituted benzoyl group $\left[\delta_{\mathrm{H}} 7.23(2 \mathrm{H}, \mathrm{d}, J=7.2 \mathrm{~Hz}), 7.49\right.$ $(1 \mathrm{H}, \mathrm{t}, J=7.2 \mathrm{~Hz})$ and $7.32(2 \mathrm{H}, \mathrm{t}, J=7.2 \mathrm{~Hz})]$, two olefinic protons $\left[\delta_{\mathrm{H}} 4.98(1 \mathrm{H}, \mathrm{t}, J=7.2 \mathrm{~Hz})\right.$ and $\left.5.03(1 \mathrm{H}, \mathrm{t}, J=7.2 \mathrm{~Hz})\right]$, one terminal double bonds $\left[\delta_{\mathrm{H}} 4.64(1 \mathrm{H}, \mathrm{s})\right.$ and $\left.4.59(1 \mathrm{H}, \mathrm{s})\right]$ and nine singlet methyl groups $\left(\delta_{\mathrm{H}} 1.30-1.69\right)$. The ${ }^{13} \mathrm{C}$ NMR data, aided by a HSQC experiment, disclosed the presence of 38 
carbon signals, including nine methyl groups, five methylene groups, 11 methine groups (7 olefinic carbons), and 13 quaternary carbons. The characteristic resonances of three nonconjugated carbonyl groups at $\delta_{\mathrm{C}} 203.0$ (C-2), 204.4 (C-4), 203.7 (C-9), four quaternary carbons at $\delta_{\mathrm{C}} 83.7$ (C-1), 74.3 (C3), 69.7 (C-5), 56.7 (C-8), two methine groups at $\delta_{\mathrm{C}} 47.1(\mathrm{C}-7)$ and 57.9 (C-32), and a methylene group at $\delta_{\mathrm{C}} 44.9$ (C-6) indicated that the molecule consists of an adamantane skeleton. In comparison of its ${ }^{1} \mathrm{H}$ and ${ }^{13} \mathrm{C}$ NMR data with those of garcimultiflorone $\mathrm{D},{ }^{6}$ an adamantane type PPAPs from the same plant, suggested that their structures were closely related, except that the diagnostic difference of chemical shifts at $\delta_{\mathrm{C}}$ 57.9 (C-32), 62.8 (C-33), and 58.9 (C-34) for 1 and $\delta_{\mathrm{C}} 51.1$ (C-32), 60.7 (C-33), and 61.1 (C-34) for garcimultiflorone D. The data indicated that 1 was 33-epimer of garcimultiflorone D. According to the literature, ${ }^{9}$ the chemical shift of C-34 was about $58 \mathrm{ppm}$ in $(33 S)$-configured 33,34-epoxide adamantane type PPAPs while in the spectrum of (33R)-configured derivatives the chemical shift of C-34 was about $62 \mathrm{ppm}$. This rule has been used to determine a number of the configurations of C-33 of 33,34-epoxide adamantane type PPAPs, which was supported by the chemical transformations and calculated ECDs. Thus, the configuration of C-33 of $\mathbf{1}$ was determined as to be $S$. The relative configurations at the chiral centers C-1, C-3, C-5, and C7 were obvious for the adamantyl core. Furthermore, H-32 was determined as $\alpha$-oriented based on NOE correlations of Me-38/ $\mathrm{H}-6 \mathrm{a}, \mathrm{Me}-37 / \mathrm{H}-32$ in the ROESY spectrum. According to the literature, ${ }^{4}$ the name gracimultiflorone $\mathrm{D}$ seems to have been given to two different compounds. Their structures of $\mathbf{1}$ and sampsonione $\mathrm{J}$ were closely related except for the isogeranyl group at C-5 in 1 instead of a geranyl group at C-5 in sampsonione $\mathrm{J}$ and the different configuration of $\mathrm{C}-33$. In order avoid to confusion, it is the best way to name $\mathbf{1}$ as epi-isosampsonione J.

Compound 2 was obtained as an amorphous powder. It gave a molecular formula of $\mathrm{C}_{38} \mathrm{H}_{48} \mathrm{O}_{5}$ according to its HR-ESI-MS at $m / z 585.35748[\mathrm{M}+\mathrm{H}]^{+}$(calcd. 585.35745). Detailed analysis of the $1 \mathrm{D}$ and $2 \mathrm{D}$ NMR spectra indicated that compound 2 featured a unique caged tetracyclo-[6.3.1.1 $\left.1^{3,10} \cdot 0^{3,7}\right]$ tridecane skeleton which was the same as those of hyperisampsins A-D. ${ }^{10}$ Comparison of the ${ }^{13} \mathrm{C}$ NMR data of 2 with that of hyperisampsin $\mathrm{C}$ revealed that two compounds were similar except for the presence of an isogeranyl group at C-5 in 2 instead of a geranyl group in hyperisampsin $\mathrm{C}$. The constitution of 2 was confirmed by HMBC correlations between $\mathrm{H}_{2}-22$ and C-5 $\left(\delta_{\mathrm{C}}\right.$ 68.2) and C-9 $\left(\delta_{\mathrm{C}}\right.$ 201.9). The relative configuration of 2 was established as the same that of hyperisampsin C by ROESY spectrum. Thus, compound 2 was established and named isohyperisampsin $\mathrm{C}$.

Compound 3 was isolated as colorless amorphous powder. Its molecular formula was determined by its ${ }^{13} \mathrm{C}$ NMR and HRESI-MS data $\left(m / z\right.$ 587.37323 $[\mathrm{M}+\mathrm{H}]^{+}$, calcd. 587.3731 $)$as $\mathrm{C}_{38} \mathrm{H}_{50} \mathrm{O}_{5}$. The ${ }^{13} \mathrm{C}$ and DEPT NMR data showed the characteristic resonances of homo-adamantane type PPAPs, including three nonconjugated carbonyl groups at $\delta_{\mathrm{C}} 206.6$ (C-2), 206.4 (C4 ) and 204.5 (C-9), four quaternary carbons at $\delta_{\mathrm{C}} 82.4$ (C-1), 72.1 (C-3), 66.9 (C-5), and $52.0(\mathrm{C}-8)$, two methine groups at $\delta_{\mathrm{C}} 43.6$
(C-7) and 57.9 (C-33), and two methylene groups at $\delta_{\mathrm{C}} 48.0$ (C-6) and 28.2 (C-32). Comparison of its ${ }^{1} \mathrm{H}$ and ${ }^{13} \mathrm{C}$ NMR data with those of hypersampsonone $\mathrm{G}^{\mathbf{1 1}}$ a known homo-adamantane type PPAP from $H$. sampsonii, suggested that they had a same tetrocyclo[7.3.1.1 $\left.1^{3,11} \cdot 0^{3,7}\right]$ tetradecane core skeleton. However, the only structural difference was an isogeranyl group at C-5 in 3 instead of a geranyl group in hypersampsonone G. This was further supported by HMBC correlations between $\mathrm{H}_{2}-22$ and C-5 $\left(\delta_{\mathrm{C}} 66.9\right), \mathrm{C}-4\left(\delta_{\mathrm{C}} 206.4\right)$ and C-9 $\left(\delta_{\mathrm{C}} 204.5\right)$. In the ROESY spectrum of 3, NOE correlations of $\mathrm{H}-7 / \mathrm{H}_{3}-37, \mathrm{H}-33 / \mathrm{H}_{3}-37, \mathrm{H}-33 / \mathrm{H}_{3}-$ 35 and $\mathrm{H}-18 / \mathrm{H}_{3}-35$ indicated that these protons were cofacial and designated as $\alpha$-oriented. Therefore, compound 3 was established and named isohypersampsonone G.

Compound 4 was isolated as amorphous powder. It had the molecular formula $\mathrm{C}_{35} \mathrm{H}_{44} \mathrm{O}_{5}$ as determined by HR-ESI-MS at $\left(\mathrm{m} / \mathrm{z} 545.32617[\mathrm{M}+\mathrm{H}]^{+}\right.$, calcd. 545.32615), with three carbon atoms less than that of 3 . In comparison of ${ }^{13} \mathrm{C}$ NMR data of 4 with those of 3, signals of C-17, C-18, and C-34 in 4 appeared at high chemical shift, suggesting that 1-hydroxy-1-methylethyl group at C-18 in 3 was replaced by a hydroxy group in $\mathbf{4}$. This was further supported by $\mathrm{HMBC}$ correlations between $\mathrm{H}_{3}-35$ and $\mathrm{H}_{3}-36$ and $\mathrm{C}-34\left(\delta_{\mathrm{C}} 49.8\right), \mathrm{C}-33\left(\delta_{\mathrm{C}} 53.2\right)$ and C-18 $\left(\delta_{\mathrm{C}} 82.0\right)$. In the ROESY spectrum of 4 , NOE correlations between $\mathrm{H}-33$ / $\mathrm{H}_{3}-37, \mathrm{H}-33 / \mathrm{H}_{3}-35$ and $\mathrm{H}-18 / \mathrm{H}_{3}-36$ suggested that $\mathrm{H}-33$ and $18-$ $\mathrm{OH}$ were $\alpha$-oriented respectively. Thus, compound 4 was assigned as depicted in Fig. 1 and was named garcimultinone A.

Compounds (5) and (6) were isolated as inseparable epimeric mixture and obtained as white amorphous powders. The ratio of 5 and 6 is about $5: 1$ by NMR analysis. Their molecular formula was determined as $\mathrm{C}_{35} \mathrm{H}_{44} \mathrm{O}_{6}$ by HR-ESI-MS data $(\mathrm{m} / \mathrm{z}$ 561.32141 $[\mathrm{M}+\mathrm{H}]^{+}$, calcd. 561.32107), Firstly, we discussed the structure elucidation of 5. Detailed analysis of the $1 \mathrm{D}$ and $2 \mathrm{D}$ NMR spectra indicated that compound $\mathbf{5}$ had an unusual hexahydrofuro[2,3-b]furan-diepoxy ring system fused in homoadamantane skeleton. Comparison of ${ }^{1} \mathrm{H}$ and ${ }^{13} \mathrm{C}$ NMR data of 5 with those of hypersampsonone $\mathrm{B}^{\mathbf{1 1}}$ indicated that the two compounds were closely related, except for an isogeranyl group at C-5 of 5 instead of a geranyl group of hypersampsonone B. The relative configuration of $\mathbf{5}$ was determined by analyzing its ROESY data. $\mathrm{H}-33$ and $18-\mathrm{OH}$ were determined as $\alpha$ and $\beta$ oriented based on the NOE correlations between $\mathrm{H}-33 / \mathrm{H}_{3}-35$ and $\mathrm{H}-18 / \mathrm{H}_{3}-35$. Except for the ${ }^{13} \mathrm{C}-\mathrm{NMR}$ signals of 5 mentioned above, the remaining 35 carbon signals were attributed to 6 . In comparison of ${ }^{1} \mathrm{H}$ and ${ }^{13} \mathrm{C}$ NMR data of 6 with those of 5, it was found that NMR data of $\mathbf{6}$ were almost identical with those of $\mathbf{5}$, except for the chemical shift of C-18 $\left(\delta_{\mathrm{C}} 98.7\right.$ in 5 and $\delta_{\mathrm{C}} 100.0 \mathrm{in}$ 6) and coupling constants between and $\mathrm{CH}_{2}-17$ and $\mathrm{H}-18\left[\delta_{\mathrm{H}}\right.$ $5.84(\mathrm{t}, J=6.6 \mathrm{~Hz})$ in 5 and $5.79(\mathrm{dd}, J=6.6,3.6 \mathrm{~Hz})$ in 6 ], indicating that 6 was a 18-epimer of 5 . Thus, compound 5 and 6 were assigned as depicted in Fig. 1 and were named isohypersampsonone $\mathrm{B}$ and epi-isohypersampsonone $\mathrm{B}$, respectively. We tried to isolate the epimeric mixture by HPLC. However, it was unsuccessful for the isolation of isohypersampsonone $\mathrm{B}$ and epi-isohypersampsonone $\mathrm{B}$ due to the rapid equilibration between the two isomeric forms.

Compound 7 was obtained white amorphous powder. It gave the molecular formula of $\mathrm{C}_{38} \mathrm{H}_{50} \mathrm{O}_{7}$ on the basis of HR-ESI-MS 

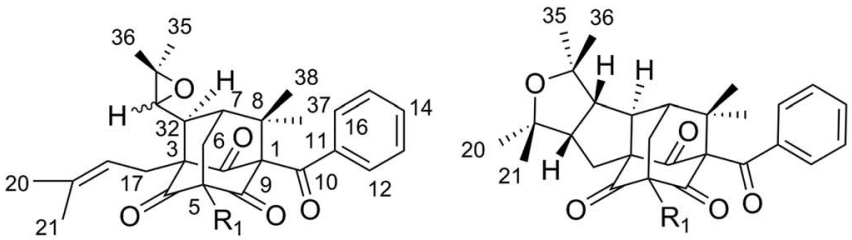

$1 \mathrm{R}_{1}=$ isogeranyl; $33 \mathrm{~S}$

$10 \mathrm{R}_{1}=$ isogeranyl; $33 R$

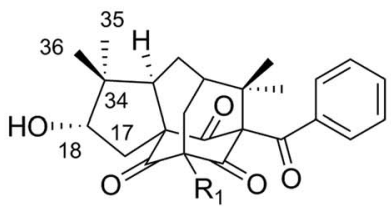

4

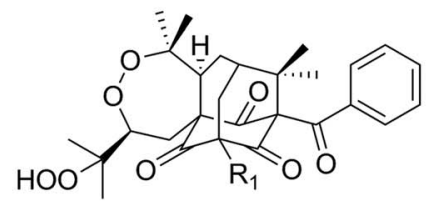

8

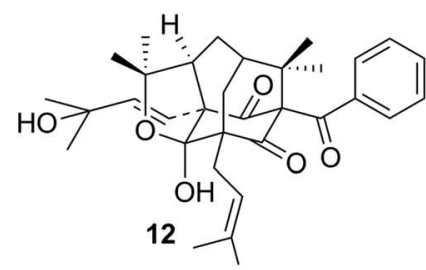

2*

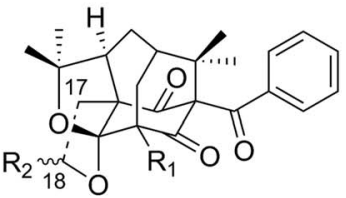

$5 \mathrm{R}_{1}=$ isogeranyl; $\mathrm{R}_{2}=\beta-\mathrm{OH}$

$6 \mathrm{R}_{1}=$ isogeranyl; $\mathrm{R}_{2}=\alpha-\mathrm{OH}$

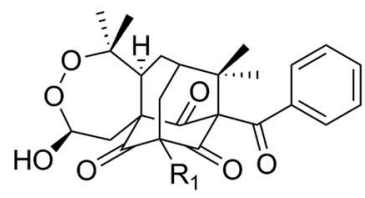

9

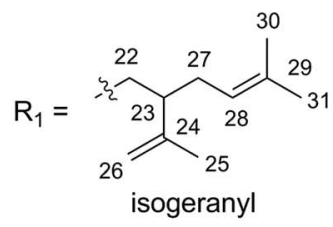

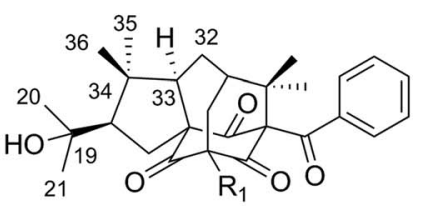

3
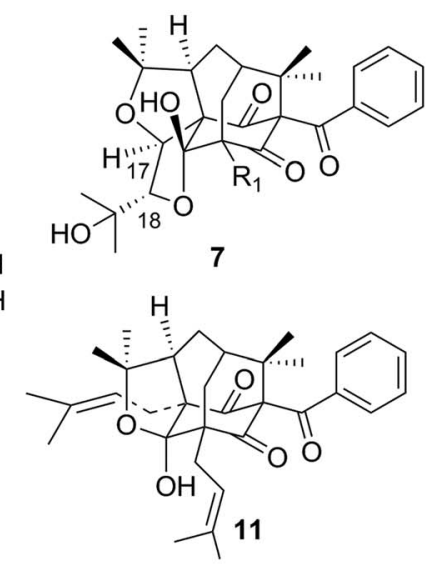

*The absolute structure of $\mathbf{2}$ was determined to be an enantiomer as shown.

Fig. 1 Structures of compounds 1-12.

data $\left(\mathrm{m} / \mathrm{z} 619.36310[\mathrm{M}+\mathrm{H}]^{+}\right.$, calcd. 619.36293). Furthermore, the NMR data of 7 were similar to those of hypersampsonone $\mathrm{C},{ }^{\mathbf{1 1}}$ indicating that 7 is also a homoadamantane derivative with an unique tetrahydrofuro[3,4-b]furan moiety. Extensive comparison of NMR data of 7 with those of hypersampsonone $\mathrm{C}$ revealed that the geranyl attached to $\mathrm{C}-5$ in hypersampsonone $\mathrm{C}$ was replaced by an isogeranyl in 7 . The constitution structure of 7 was also confirmed by 2D-NMR spectroscopy. The relative configuration of 7 was assigned to be the same as that of hypersampsonone $\mathrm{C}$ by comparison of its $1 \mathrm{D}$ NMR and ROESY data with those of hypersampsonone C. Thus, the structure of 7 was deduced completely as showed in Fig. 1 and was named isohypersampsonone $\mathrm{C}$.

Compound 8 was isolated as amorphous powder. Its molecular formula was determined by its ${ }^{13} \mathrm{C}$ NMR and HR-ESIMS data $\left(m / z 635.35791[\mathrm{M}+\mathrm{H}]^{+}\right.$, calcd. 635.35784) as $\mathrm{C}_{38} \mathrm{H}_{50} \mathrm{O}_{8}$, with one more O-atom than that of garcimultiflorone $\mathrm{G}^{\mathbf{8}}$ Furthermore, these NMR data showed high degrees of similarity to those of hyperisampsin $\mathrm{O},{ }^{\mathbf{1 2}}$ which suggested that $\mathbf{8}$ is also a homoadamantane PPAP with an 1,2-dioxepane functionality. In comparison with those of hyperisampsin $\mathrm{O}$ indicated that $\mathbf{8}$ possessed an isogeranyl at C-5 instead of a geranyl at C-5 in hyperisampsin $\mathrm{O}$. In the ROESY spectrum of 8 , NOE correlations between $\mathrm{H}-33 / \mathrm{H}_{3}-35, \mathrm{H}-18 / \mathrm{H}-33$ and $\mathrm{H}_{3}-37 / \mathrm{H}-33$ implied that both $\mathrm{H}-18$ and $\mathrm{H}-33$ were $\alpha$-oriented. Therefore, compound
8 was assigned as depicted in Fig. 1 and was named isohyperisampsin $\mathrm{O}$.

Compound 9 was isolated as amorphous powder. It had the molecular formula $\mathrm{C}_{35} \mathrm{H}_{44} \mathrm{O}_{7}$ as determined by HR-ESI-MS at $\left(\mathrm{m} / \mathrm{z} 577.31610[\mathrm{M}+\mathrm{H}]^{+}\right.$, calcd. 577.31598), with three carbon atoms less than that of $\mathbf{8}$. In comparison with $\mathbf{8}$, signals of $\mathrm{C}-17$ and C-18 in 9 appeared at high chemical shift, suggesting that 1hydroperoxy-1-methylethyl group at C-18 in 8 was replaced by a hydroxy group in 9. This was further supported by HMBC correlations from $\mathrm{H}_{2}-17$ to $\mathrm{C}-3\left(\delta_{\mathrm{C}} 66.6\right), \mathrm{C}-18\left(\delta_{\mathrm{C}} 99.8\right), \mathrm{C}-2\left(\delta_{\mathrm{C}}\right.$ 208.4) and $\mathrm{C}-4\left(\delta_{\mathrm{C}} 205.4\right)$. 18-OH configuration was established as $\beta$-oriented based on the NOE correlations between $\mathrm{H}-18 / \mathrm{H}$ $33, \mathrm{H}-33 / \mathrm{H}_{3}-35$ in the ROESY spectrum of 9 . Thus, compound 9 was assigned as depicted and was named garcimultinone B (Fig. 2-4).

The absolute stereochemistry of 1-9 were assigned by CD analysis. Nine new isolates were elucidated to possess adamantyl and homoadamantyl skeleton with an isogeranyl group. Considering the isogeranyl group away from the chromophoric system, the absolute configuration of C-23 has an insignificant effect on the CD spectrum. ${ }^{13}$ Thus, the absolute configurations of compounds 1-9 except C-23 can be determined by comparison of their CD curves with those of known compounds. Compounds 1 (adamantane type) and 3-9 (homoadamantyl type) displayed the negative Cotton effect around $330 \mathrm{~nm}$, 


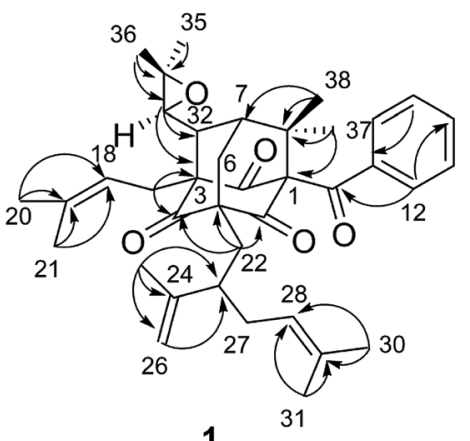

1

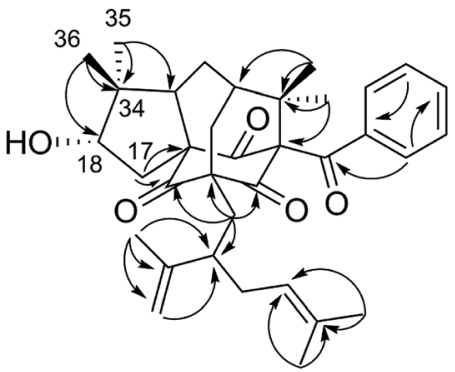

4

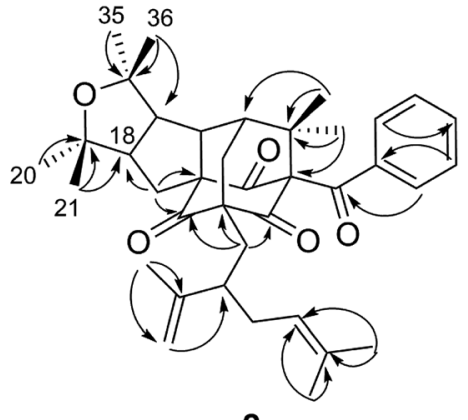

2

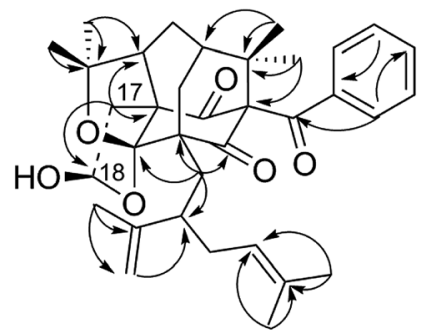

5

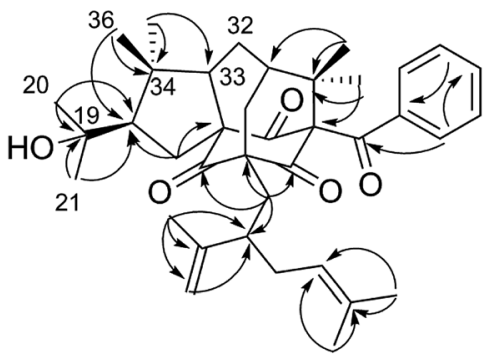

3

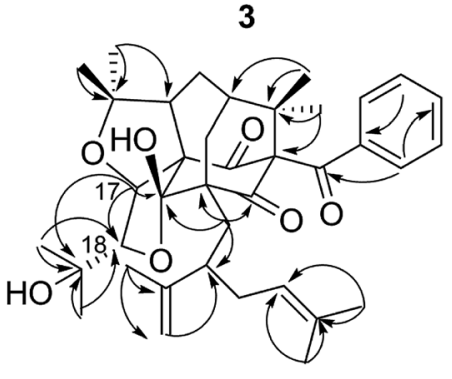

7

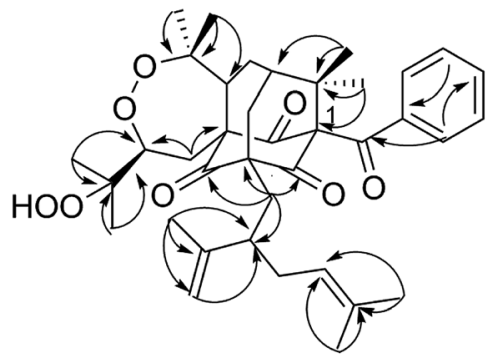

8

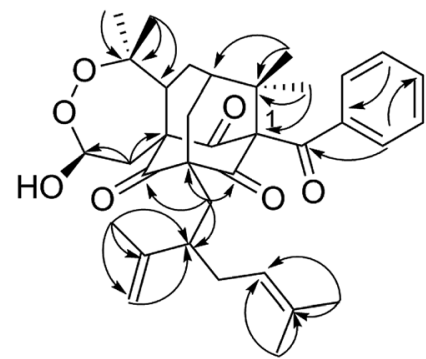

9

Fig. 2 Key HMBC correlations of compounds 1-9.

indicating $1 R$ configuration based on the $\mathrm{CD}$ benchmark summarized by Zhang et $a l .{ }^{10}$ Furthermore, the ECD spectra of 1, 3 and 5-8 matched well those of known compounds hyperisampsin $\mathrm{G},{ }^{10}$ hypersampsonone $\mathrm{G},{ }^{11}$ hypersampsonone $\mathrm{B},{ }^{11}$ hypersampsonone $\mathrm{C}^{11}$ and hyperisampsins $\mathrm{O}^{12}$ respectively, in which the main differences in their structure are that the former have an isogeranyl group attached to C-5 position, while the latter have a geranyl group. Hence, the absolute configuration of $\mathbf{1}$ and 3-9 was assigned as depicted in Fig. 1. The absolute configuration of C-1 for most of naturally occurring adamantyl and homoadamantyl PPAPs appeared as $1 R$, which showed the negative CE at $333 \mathrm{~nm} .{ }^{10}$ However, a positive Cotton effect at $325 \mathrm{~nm}$ and a negative Cotton effect at 243 and $294 \mathrm{~nm}$ were observed in ECD spectrum of 2, which was the opposite to those of hyperisampsin C. ${ }^{10}$ Consequently, the absolute configuration of 2 was established as depicted in Fig. 1.

The known compounds garcimultiflorone D (10), ${ }^{6}$ sampsonione B $(\mathbf{1 1})^{14}$ and hyphenrone $\mathrm{M}(\mathbf{1 2})^{15}$ were identified by comparison of their NMR data with those in the literature.

All the isolated compounds were assessed for their cytotoxic effects against three human tumor cell lines (SGC-7901, HepG2, HCT-116) by CCK-8 method. In comparison with the positive control cisplatin against SGC-7901, HepG2 and HCT-116 with
$\mathrm{IC}_{50}$ values $7.35,4.58$ and $8.23 \mu \mathrm{M}$ respectively, compounds 8 showed mild cytotoxicity against SGC-7901 and HepG2 with an $\mathrm{IC}_{50}$ values of 13.05 and $18.05 \mu \mathrm{M}$, and compounds 12 also displayed mild cytotoxicity against three tested human cancer cells with an $\mathrm{IC}_{50}$ values of $17.63,19.64$, and $18.93 \mu \mathrm{M}$ respectively. The other compounds showed no obvious cytotoxicity against three tested human cancer cells $\left(\mathrm{IC}_{50}>20 \mu \mathrm{M}\right)$. Additionally, the NO production inhibitory activity of all isolated compounds on LPS-activated RAW 264.7 cells was also tested. The cell viability was first confirmed by the CCK-8 method to determine whether the cytotoxicity of the tested compounds resulted in the inhibition of NO production. Compounds $\mathbf{8}$ and 12 also exhibited NO production inhibitory effect with $\mathrm{IC}_{50}$ values 18.24 and $12.50 \mu \mathrm{M}$ respectively, while did not obviously affect cell viability up to $20 \mu \mathrm{M}$ and the others compounds had no inhibitory activity $\left(\mathrm{IC}_{50}>20 \mu \mathrm{M}\right)$.

\section{Materials and methods}

\subsection{General experimental procedures}

Optical rotations were determined in $\mathrm{MeOH}$ on an Autopol IV polarimeter (Rudolph Research Analytical, Hackettstown, NJ, USA). UV spectra were obtained on a UH5300 UV-VIS Double 

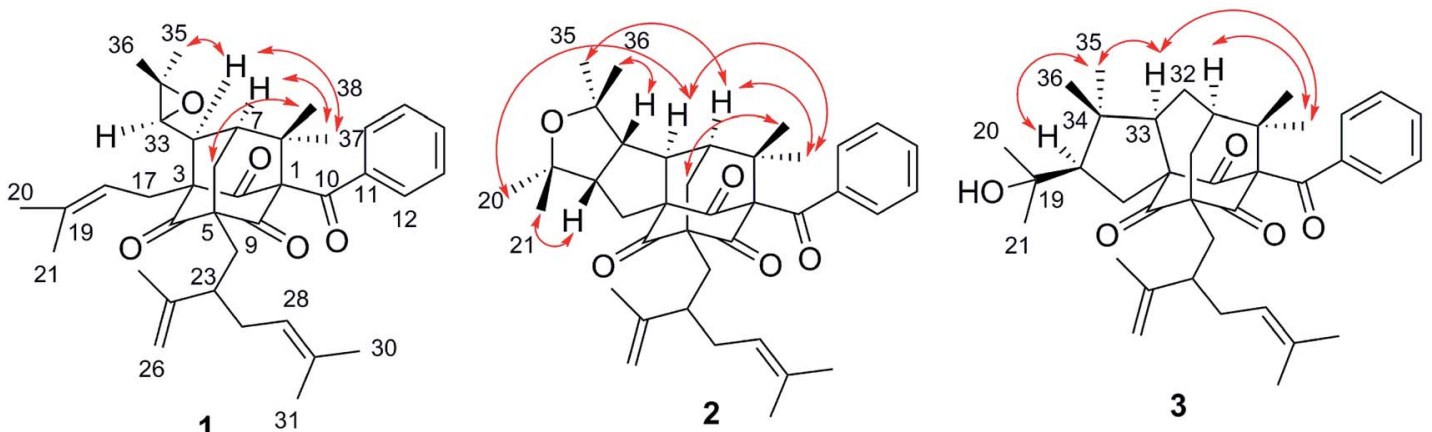

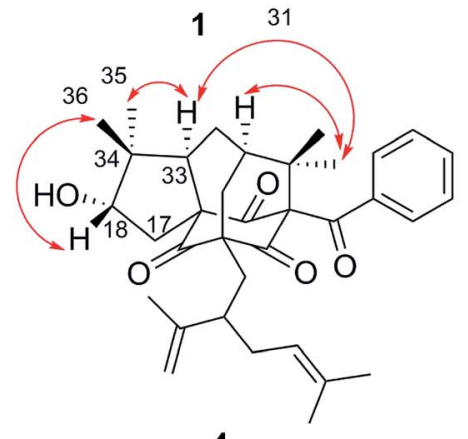

4

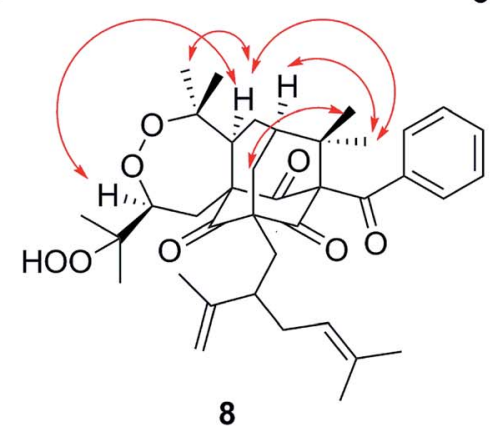

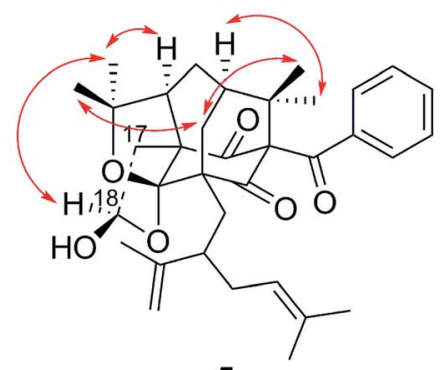

5

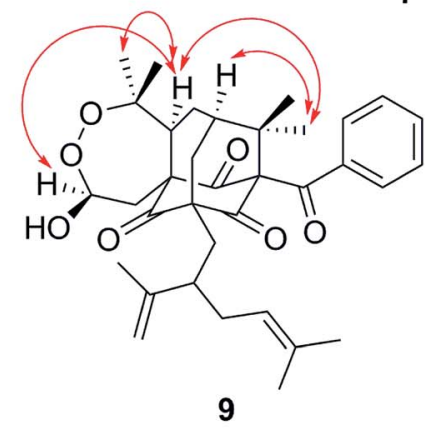

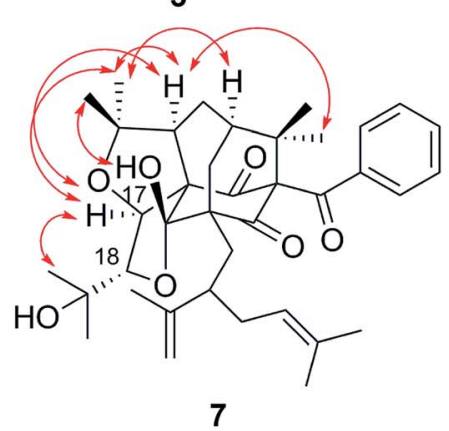

7

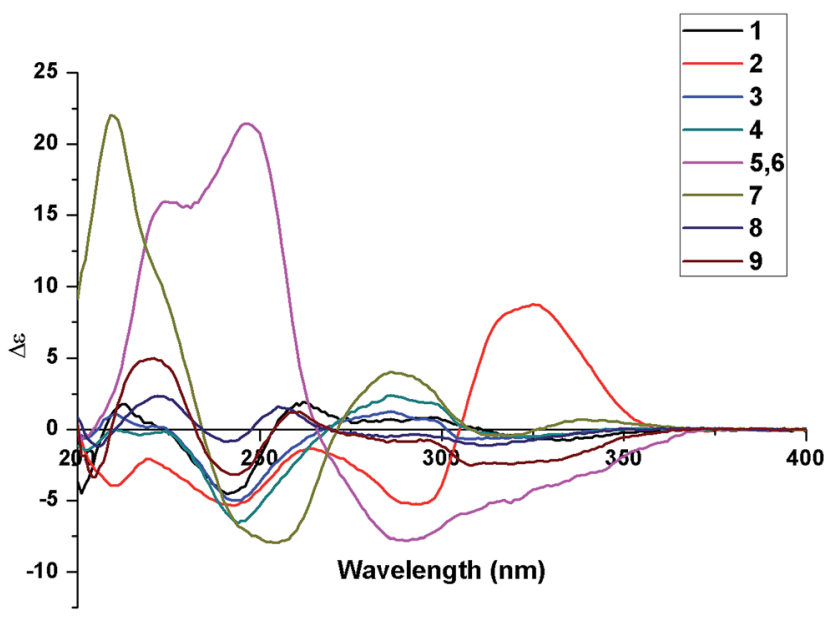

Fig. 4 CD spectra of compounds 1-9.

Beam spectrophotometer (Hitachi Co., Tokyo, Japan). ECD spectra were recorded on a Chirascan Plus spectrometer (Applied Photophysics Ltd, London, England). 1D and 2D NMR spectra were recorded on a Bruker AVANCE IIITM $600 \mathrm{MHz}$ spectrometer (Bruker, Ettlingen, Germany) in $\mathrm{CDCl}_{3}, \mathrm{CD}_{3} \mathrm{OD}$ using tetramethylsilane (TMS) as an internal reference standard. Chemical shifts $(\delta)$ have been expressed in ppm and the coupling constants $(J)$ have been given in Hz. High-resolution electrospray mass spectroscopy was performed on an Thermo Scientific Q Exactive Orbitrap LC-MS/MS System (HR-ESI-MS) (Thermo Scientific, Waltham, MA, USA). High-performance liquid chromatography (HPLC) was conducted on an Ultimate 3000 HPLC system (Dionex Co., Sunnyvale, CA, USA) equipped with an Ultimate 3000 pump and Ultimate 3000 Variable Wavelength detector, as well as a semi-preparative YMC-Pack ODS-A column $(250 \times 10 \mathrm{~mm}, 5 \mu \mathrm{m})$ and a preparative YMCPack ODS-A column $(250 \times 20 \mathrm{~mm}, 5 \mu \mathrm{m})$ from YMC Co., Ltd (Kyoto, Japan), column chromatography (CC) was conducted over silica gel (200-300 mesh and 300-400 mesh, Qingdao Haiyang Chemical Industry Co., Ltd., Qingdao, China). Chromatographic grade acetonitrile was purchased from Chang Tech Enterprise Co., Ltd (Taiwan, China). RAW 264.7 murine macrophages and three human tumor cell lines (SGC-7901, HepG2, HCT-116) were purchased from the cell bank of Chinese Academy of Sciences (Shanghai, China). Cisplatin was purchased from Sigma Chemical Co. Ltd. (St. Louis, MO, USA). Dexamethasone and lipopolysaccharides (LPS) were purchased from Sigma Chemical Co. Ltd. (St. Louis, MO, USA). Cell 
Counting Kit (CCK-8) was purchased from Beyotime Biotechnology (shanghai, China). Dulbecco modified Eagle medium (DMEM) and Penicillin-Streptomycin solution were purchased from GE healthcare life science (Logan, UT, USA). Fetal bovine serum (FBS) was purchased from Gibco, Life technologies (Grand Island, NY, USA). Reagent grade dimethyl sulfoxide (DMSO) was purchased from Vetec, Sigma Chemical Co. (St. Louis, MO, USA). The absorbance was read on a Multiskan GO microplate reader (Thermo Fisher Scientific Inc. Waltham, MA, USA).

\subsection{Plant material}

The fruits of $G$. multiflora were purchased from Nanning, Guangxi Zhuang Autonomous Region, P. R. China and identified by Prof. Hongli Teng, Guangxi Zhuang medicine international hospital. The voucher specimen (2014091201) was deposited in the herbarium of School of Pharmaceutical Sciences, South Central University for Nationalities.

\subsection{Extraction and isolation}

The dried fruits of G. multiflora Champ (5.2 kg) were powdered and extracted with $95 \% \mathrm{EtOH}$ at room temperature for three times (each time for $24 \mathrm{~h}$ ) to obtain EtOH extract $2.21 \mathrm{~kg}$, and then successively partitioned with petroleum ether (PE), EtOAc and $n$-BuOH to get PE extract $125 \mathrm{~g}$, EtOAc extract $166 \mathrm{~g}, n$-BuOH extract $80 \mathrm{~g}$. The PE extract (125 g) was chromatographed on a silica gel column (200-300 mesh) eluted successively with PEacetone gradient $(50: 1,25: 1,10: 1,7: 3,1: 1,0: 1)$ to obtain 6 fractions (Fr. 1-Fr. 6). Fr. 2 (42.5 g) was divided into 11 frac-

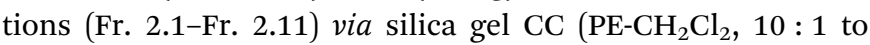
$0: 1)$. Fr. 2.9 (2.3 g) was further separated by silica gel CC (PE/ $\mathrm{CH}_{2} \mathrm{Cl}_{2} / \mathrm{MeOH}, 10: 1: 0.1$ to $\left.0: 1: 0.1\right)$ and repeated semipreparative HPLC to give compounds 2 (1.2 mg; $\mathrm{CH}_{3} \mathrm{CN}-\mathrm{H}_{2} \mathrm{O}$, $\left.90: 10 ; t_{\mathrm{R}} 19.6 \mathrm{~min}\right) ; 4$ (1.1 mg; $\mathrm{CH}_{3} \mathrm{CN}-\mathrm{H}_{2} \mathrm{O}, 90: 10, t_{\mathrm{R}} 14.8$ $\min ) ; 8$ (3.2 mg, $\left.\mathrm{CH}_{3} \mathrm{CN}-\mathrm{H}_{2} \mathrm{O}, 95: 5, t_{\mathrm{R}} 10.3 \mathrm{~min}\right) ; 9$ (9.6 mg, $\mathrm{CH}_{3} \mathrm{CN}-\mathrm{H}_{2} \mathrm{O}, 94: 6, t_{\mathrm{R}} 8.4 \mathrm{~min}$ ) and 10 (1.2 mg; $\mathrm{MeOH}-\mathrm{H}_{2} \mathrm{O}$, $\left.95: 5 ; t_{\mathrm{R}} 16.2 \mathrm{~min}\right)$. In the same way, Fr. $3(31.0 \mathrm{~g})$ was subjected to repeated silica gel CC with $\mathrm{PE}-\mathrm{CH}_{2} \mathrm{Cl}_{2}(50: 1$ to $0: 1)$, ODS CC with $\mathrm{H}_{2} \mathrm{O}-\mathrm{MeOH}(7: 3$ to $0: 1)$ and semi-preparative HPLC to afford 1 (3.2 mg; $\mathrm{CH}_{3} \mathrm{CN}-\mathrm{H}_{2} \mathrm{O}, 96: 4, t_{\mathrm{R}} 10.3 \mathrm{~min}$ ); 3 (1.0 mg, $\left.\mathrm{MeOH}-\mathrm{H}_{2} \mathrm{O}, 90: 10, t_{\mathrm{R}} 19.6 \mathrm{~min}\right)$; the mixture of 5 and 6 (6.5 mg, MeOH- $\left.\mathrm{H}_{2} \mathrm{O}, 87: 13, t_{\mathrm{R}} 16.4 \mathrm{~min}\right) ; 7$ (1.8 mg, МeOH$\left.\mathrm{H}_{2} \mathrm{O}, 90: 10, t_{\mathrm{R}} 16.2 \mathrm{~min}\right) ; 11\left(3.1 \mathrm{mg}, \mathrm{CH}_{3} \mathrm{CN}-\mathrm{H}_{2} \mathrm{O}, 79: 21, t_{\mathrm{R}}\right.$ $30.9 \mathrm{~min}$ ); 12 (3.0 mg MeOH- $\mathrm{H}_{2} \mathrm{O}, 85: 15, t_{\mathrm{R}} 12.9 \mathrm{~min}$ ).

Epi-isosampsonione $\mathrm{J}(\mathbf{1})$, white amorphous powder. $[\alpha]_{\mathrm{D}}=$ $+55.0^{\circ}(c=0.02, \mathrm{MeOH}) ; \mathrm{UV}(\mathrm{MeOH}) \lambda_{\max } \mathrm{nm}(\log \varepsilon): 215(\mathrm{sh})$ (3.88), 245 (4.02); $\operatorname{ECD}\left(c 3.42 \times 10^{-4} \mathrm{M}, \mathrm{MeOH}\right) \lambda(\Delta \varepsilon): 213$ (+1.80), 241 (-4.55), $262(+1.94), 293(+0.82), 335(-0.77) ;{ }^{1} \mathrm{H}-$ and ${ }^{13} \mathrm{C}-\mathrm{NMR}$ see Tables 1 and 3; HR-ESI-MS m/z: 583.34296 [M $-\mathrm{H}]^{-}$(calcd for $\mathrm{C}_{38} \mathrm{H}_{47} \mathrm{O}_{5}{ }^{-}$: 583.3429).

Isohyperisampsin $\mathrm{C}(2)$, white amorphous powder. $[\alpha]_{\mathrm{D}}=$ $+93.3^{\circ}(c=0.02, \mathrm{MeOH}) ; \mathrm{UV}(\mathrm{MeOH}) \lambda_{\max } \mathrm{nm}(\log \varepsilon): 210$ (3.87), 250 (3.87), 295 (3.42), 325 (3.41); ECD (c $3.42 \times 10^{-4} \mathrm{M}$,

Table $1{ }^{1} \mathrm{H}$-NMR spectroscopic data of compounds $1-4$ ( $\delta$ in ppm, $\mathrm{J}$ in $\mathrm{Hz}$ )

\begin{tabular}{|c|c|c|c|c|}
\hline No. & $\mathbf{1}^{a}$ & $2^{b}$ & $3^{b}$ & $4^{b}$ \\
\hline \multirow[t]{2}{*}{6} & $2.69-2.78 \mathrm{~m}$ & 2.74 d (14.4); & 2.55 dd $(13.2,6.0)$ & 2.56 dd $(13.8,5.4)$ \\
\hline & $2.41-2.48 \mathrm{~m}$ & $2.40-2.47 \mathrm{~m}$ & $1.75-1.82 \mathrm{~m}$ & $1.76-1.82 \mathrm{~m}$ \\
\hline 7 & $1.82-1.88 \mathrm{~m}$ & $1.88-1.94 \mathrm{~m}$ & $2.13 \mathrm{t}(6.6)$ & $2.13-2.19 \mathrm{~m}$ \\
\hline $12 / 16$ & $7.23 \mathrm{~d}(7.2)$ & $7.22 \mathrm{~d}(7.2)$ & $7.31 \mathrm{~m}$ & $7.34 \mathrm{~d}(7.2)$ \\
\hline $13 / 15$ & $7.32 \mathrm{t}(7.2)$ & $7.37 \mathrm{t}(7.2)$ & $7.31 \mathrm{~m}$ & $7.31 \mathrm{t}(7.2)$ \\
\hline 14 & $7.49 \mathrm{t}(7.2)$ & $7.44 \mathrm{t}(7.2)$ & $7.43 \mathrm{~m}$ & $7.45 \mathrm{t}(7.2)$ \\
\hline \multirow[t]{2}{*}{17} & $2.80 \mathrm{dd}(15.0,7.2) ; 2.31 \mathrm{dd}$ & 2.15 dd $(14.4,6.6)$ & 2.84 dd $(13.2,12.0)$ & 3.16 dd $(15.0,4.8)$ \\
\hline & $(15.0,7.2)$ & $2.38-2.45 \mathrm{~m}$ & $2.47 \mathrm{dd}(13.2,9.0)$ & $2.13-2.20 \mathrm{~m}$ \\
\hline 18 & $4.98 \mathrm{t}(7.2)$ & $2.99-3.06 \mathrm{~m}$ & 1.96 dd $(12.0,9.0)$ & $4.00 \mathrm{t}(6.6)$ \\
\hline 20 & $1.69 \mathrm{~s}$ & $1.20 \mathrm{~s}$ & $1.33 \mathrm{~s}$ & \\
\hline 21 & $1.63 \mathrm{~s}$ & $1.36 \mathrm{~s}$ & $1.41 \mathrm{~s}$ & \\
\hline \multirow[t]{2}{*}{22} & $2.03-2.14 \mathrm{~m} ; 1.80-1.88 \mathrm{~m}$ & $2.05-2.13 \mathrm{~m}$ & 2.23 dd $(14.4,10.2)$ & 2.88 dd $(14.4,10.2)$ \\
\hline & & $1.87 \mathrm{dd}(15.0,3.0)$ & $1.75-1.82 \mathrm{~m}$ & $1.78-1.84 \mathrm{~m}$ \\
\hline 23 & $2.68-2.79 \mathrm{~m}$ & $2.45-2.53 \mathrm{~m}$ & $2.56-2.64 \mathrm{~m}$ & $2.60-2.67 \mathrm{~m}$ \\
\hline 25 & $1.57 \mathrm{~s}$ & $1.69 \mathrm{~s}$ & $1.45 \mathrm{~s}$ & $1.42 \mathrm{~s}$ \\
\hline 26 & $4.64 \mathrm{~s} ; 4.59 \mathrm{~s}$ & $4.72 \mathrm{~s} ; 4.68 \mathrm{~s}$ & 4.53 br s; 4.66 br s & 4.67 br s; 4.47 br s \\
\hline 27 & $2.03-2.13 \mathrm{~m}$ & $2.05-2.17 \mathrm{~m}$ & $1.97-2.04 \mathrm{~m}$ & $1.94-2.03 \mathrm{~m}$ \\
\hline 28 & $5.03 \mathrm{t}(7.2)$ & $5.02 \mathrm{t}(6.6)$ & $5.00 \mathrm{t}(7.2)$ & $4.99 \mathrm{t}(6.6)$ \\
\hline 30 & $1.63 \mathrm{~s}$ & $1.60 \mathrm{~s}$ & $1.60 \mathrm{~s}$ & $1.60 \mathrm{~s}$ \\
\hline 31 & $1.67 \mathrm{~s}$ & $1.66 \mathrm{~s}$ & $1.68 \mathrm{~s}$ & $1.69 \mathrm{~s}$ \\
\hline \multirow[t]{2}{*}{32} & $2.42-2.48 \mathrm{~m}$ & $3.02-3.09 \mathrm{~m}$ & 2.19 dd $(13.8,7.2)$ & $2.17-2.24 \mathrm{~m}$ \\
\hline & & & $1.43-1.52 \mathrm{~m}$ & $1.44-1.51 \mathrm{~m}$ \\
\hline 33 & $2.74-2.80 \mathrm{~m}$ & $2.40-2.48 \mathrm{~m}$ & $2.06 \mathrm{dd}(12.0,7.8)$ & $2.38 \mathrm{dd}(13.2,7.8)$ \\
\hline 35 & $1.30 \mathrm{~s}$ & $1.23 \mathrm{~s}$ & $1.11 \mathrm{~s}$ & $1.02 \mathrm{~s}$ \\
\hline 36 & $1.32 \mathrm{~s}$ & $1.30 \mathrm{~s}$ & $1.07 \mathrm{~s}$ & $0.99 \mathrm{~s}$ \\
\hline 37 & $1.36 \mathrm{~s}$ & $1.52 \mathrm{~s}$ & $1.54 \mathrm{~s}$ & $1.59 \mathrm{~s}$ \\
\hline 38 & $1.44 \mathrm{~s}$ & $1.53 \mathrm{~s}$ & $1.41 \mathrm{~s}$ & $1.43 \mathrm{~s}$ \\
\hline
\end{tabular}

${ }^{a}$ Recorded in $\mathrm{CD}_{3} \mathrm{OD} .{ }^{b}$ Recorded in $\mathrm{CDCl}_{3}$. 
Table $2{ }^{1} \mathrm{H}$-NMR spectroscopic data of compounds $5-9$ in $\mathrm{CDCl}_{3}(\delta$ in ppm, $\mathrm{J}$ in $\mathrm{Hz}$ )

\begin{tabular}{|c|c|c|c|c|c|}
\hline No. & 5 & 6 & 7 & 8 & 9 \\
\hline 6 & $\begin{array}{l}2.61 \text { dd }(15.0,6.6) ; \\
2.19 \text { d }(16.2)\end{array}$ & $\begin{array}{l}2.61 \text { dd }(15.0,6.6) ; \\
2.19 \text { d }(16.2)\end{array}$ & $2.29-2.39 \mathrm{~m}$ & $\begin{array}{l}2.68 \text { dd }(14.4,6.6) ; \\
1.80 \text { d }(13.8)\end{array}$ & $\begin{array}{l}2.57-2.64 \mathrm{~m} ; \\
1.77-1.84 \mathrm{~m}\end{array}$ \\
\hline 7 & $1.73-1.81 \mathrm{~m}$ & $1.73-1.81 \mathrm{~m}$ & $1.96-2.03 \mathrm{~m}$ & $2.05-2.13 \mathrm{~m}$ & $2.05-2.10 \mathrm{~m}$ \\
\hline $12 / 16$ & $7.56 \mathrm{~d}(7.2)$ & $7.56 \mathrm{~d}(7.2)$ & $7.58 \mathrm{~d}(8.4)$ & $7.31 \mathrm{~m}$ & $7.33 \mathrm{~m}$ \\
\hline $13 / 15$ & 7.38 t $(7.8)$ & $7.38 \mathrm{t}(7.8)$ & $7.26 \mathrm{t}(7.8)$ & $7.31 \mathrm{~m}$ & $7.33 \mathrm{~m}$ \\
\hline 14 & $7.43 \mathrm{t}(7.8)$ & $7.43 \mathrm{t}(7.8)$ & $7.39 \mathrm{t}(7.8)$ & $7.43 \mathrm{~m}$ & $7.46 \mathrm{~m}$ \\
\hline 17 & $\begin{array}{l}2.99 \mathrm{dd}(16.2,6.6) ; \\
2.39-2.47 \mathrm{~m}\end{array}$ & $2.89-2.96 \mathrm{~m} ; 2.39-2.47 \mathrm{~m}$ & $5.07 \mathrm{~d}(2.4)$ & $\begin{array}{l}3.44 \text { dd }(14.0,11.4) ; \\
1.64 \text { dd }(15.0,3.0)\end{array}$ & $\begin{array}{l}3.30 \mathrm{dd}(15.0,9.0) ; \\
1.74-1.82 \mathrm{~m}\end{array}$ \\
\hline 18 & $5.84 \mathrm{t}(6.6)$ & $5.79 \mathrm{dd}(6.6,3.6)$ & $3.92 \mathrm{~d}(2.4)$ & $4.94 \mathrm{dd}(11.4,3.0)$ & $5.86-5.92 \mathrm{~m}$ \\
\hline 20 & & & $1.26 \mathrm{~s}$ & $1.19 \mathrm{~s}$ & \\
\hline 21 & & & $1.33 \mathrm{~s}$ & $1.20 \mathrm{~s}$ & \\
\hline 22 & $2.20-2.29 \mathrm{~m} ; 2.04-2.14 \mathrm{~m}$ & $2.20-2.29 \mathrm{~m} ; 2.04-2.14 \mathrm{~m}$ & $\begin{array}{l}2.14-2.22 \mathrm{~m} \\
2.04-2.11 \mathrm{~m}\end{array}$ & $\begin{array}{l}2.28 \text { dd }(14.4,9.6) ; \\
1.85 \text { dd }(14.4,4.2)\end{array}$ & $\begin{array}{l}2.28 \mathrm{dd}(14.4,9.6) ; \\
1.77-1.84 \mathrm{~m}\end{array}$ \\
\hline 23 & $2.36-2.44 \mathrm{~m}$ & $2.36-2.44 \mathrm{~m}$ & $2.50-2.57 \mathrm{~m}$ & $2.57-2.65 \mathrm{~m}$ & $2.58-2.66 \mathrm{~m}$ \\
\hline 25 & $1.69 \mathrm{~s}$ & $1.70 \mathrm{~s}$ & $1.72 \mathrm{~s}$ & $1.56 \mathrm{~s}$ & $1.50 \mathrm{~s}$ \\
\hline 26 & $4.73 \mathrm{~s}$ & $4.73 \mathrm{~s}$ & $4.79 \mathrm{~s} ; 4.81 \mathrm{~s}$ & $4.70 \mathrm{~s} ; 4.62 \mathrm{~s}$ & 4.57 br s; 4.70 br s \\
\hline 27 & $2.00-2.07 \mathrm{~m} ; 1.87-1.95 \mathrm{~m}$ & $2.00-2.07 \mathrm{~m} ; 1.87-1.95 \mathrm{~m}$ & $\begin{array}{l}2.10-2.16 \mathrm{~m} \\
2.01-2.07 \mathrm{~m}\end{array}$ & $2.04-2.14 \mathrm{~m}$ & $2.01-2.07 \mathrm{~m}$ \\
\hline 28 & 5.07 t (6.6) & 5.07 t (6.6) & $5.03-5.09 \mathrm{~m}$ & $5.03 \mathrm{t}(6.6)$ & $5.00 \mathrm{t}(6.6)$ \\
\hline 30 & $1.55 \mathrm{~s}$ & $1.56 \mathrm{~s}$ & $1.59 \mathrm{~s}$ & $1.62 \mathrm{~s}$ & $1.61 \mathrm{~s}$ \\
\hline 31 & $1.64 \mathrm{~s}$ & $1.64 \mathrm{~s}$ & $1.65 \mathrm{~s}$ & $1.69 \mathrm{~s}$ & $1.68 \mathrm{~s}$ \\
\hline 32 & $1.87-2.02 \mathrm{~m}$ & $1.87-2.02 \mathrm{~m}$ & $\begin{array}{l}2.04-2.10 \mathrm{~m} \\
1.97-2.04 \mathrm{~m}\end{array}$ & $\begin{array}{l}2.31-2.40 \mathrm{~m} ; \\
1.45-1.55 \mathrm{~m}\end{array}$ & $\begin{array}{l}2.33 \mathrm{dd}(13.8,7.2) ; \\
1.45-1.52 \mathrm{~m}\end{array}$ \\
\hline 33 & $2.41-2.48 \mathrm{~m}$ & $2.50-2.55 \mathrm{~m}$ & $2.46-2.53 \mathrm{~m}$ & $2.72 \mathrm{t}(10.2)$ & $2.58-2.66 \mathrm{~m}$ \\
\hline 35 & $1.58 \mathrm{~s}$ & $1.70 \mathrm{~s}$ & $1.37 \mathrm{~s}$ & $1.33 \mathrm{~s}$ & $1.32 \mathrm{~s}$ \\
\hline 36 & $1.46 \mathrm{~s}$ & $1.50 \mathrm{~s}$ & $1.34 \mathrm{~s}$ & $1.20 \mathrm{~s}$ & $1.25 \mathrm{~s}$ \\
\hline 37 & $1.21 \mathrm{~s}$ & $1.19 \mathrm{~s}$ & $1.44 \mathrm{~s}$ & $1.35 \mathrm{~s}$ & $1.39 \mathrm{~s}$ \\
\hline 38 & $1.47 \mathrm{~s}$ & $1.47 \mathrm{~s}$ & $1.39 \mathrm{~s}$ & $1.48 \mathrm{~s}$ & $1.44 \mathrm{~s}$ \\
\hline $\mathrm{OH}$ & & & $4.75 \mathrm{~s}$ & & \\
\hline
\end{tabular}

$\mathrm{MeOH}) \lambda(\Delta \varepsilon): 219(-2.07), 243(-5.36), 264$ (-1.32), 294 $(-5.29), 325(+8.79) ;{ }^{1} \mathrm{H}$ - and ${ }^{13} \mathrm{C}-\mathrm{NMR}$ see Tables 1 and 3 . HRESI-MS $m / z: 585.35748[\mathrm{M}+\mathrm{H}]^{+}$(calcd for $\mathrm{C}_{38} \mathrm{H}_{49} \mathrm{O}_{5}{ }^{+}$: 585.35745).

Isohypersampsonone $\mathrm{G}(3)$, white, amorphous powder. $[\alpha]_{\mathrm{D}}$ $=+34.2^{\circ}(c=0.01, \mathrm{MeOH}) ; \mathrm{UV}(\mathrm{MeOH}) \lambda_{\max } \mathrm{nm}(\log \varepsilon): 210$ (4.14), 245 (4.12); $\operatorname{ECD}\left(c 1.71 \times 10^{-4} \mathrm{M}, \mathrm{MeOH}\right) \lambda(\Delta \varepsilon): 210$ $(-0.03), 244(-6.56), 286(+2.40), 321(-0.55) ;{ }^{1} \mathrm{H}-$ and ${ }^{13} \mathrm{C}-\mathrm{NMR}$ see Tables 1 and 3; HR-ESI-MS $m / z: 587.37323[\mathrm{M}+\mathrm{H}]^{+}$(calcd for $\mathrm{C}_{38} \mathrm{H}_{51} \mathrm{O}_{5}^{+}$: 587.37310).

Garcimultinone A (4), white amorphous powder. $[\alpha]_{\mathrm{D}}=$ $-25.6^{\circ}(c=0.02, \mathrm{MeOH}) ; \mathrm{UV}(\mathrm{MeOH}) \lambda_{\max } \mathrm{nm}(\log \varepsilon): 210$ (3.80), 245 (3.79); $\operatorname{ECD}\left(c 3.68 \times 10^{-4} \mathrm{M}, \mathrm{MeOH}\right) \lambda(\Delta \varepsilon): 210(+1.06), 244$ $(-5.00), 286(+1.24), 307(-0.71) ;{ }^{1} \mathrm{H}-$ and ${ }^{13} \mathrm{C}-\mathrm{NMR}$ see Tables 1 and 3; HR-ESI-MS $m / z: 545.32617[\mathrm{M}+\mathrm{H}]^{+}$(calcd for $\mathrm{C}_{35} \mathrm{H}_{45} \mathrm{O}_{5}{ }^{+}$: 545.32615).

Isohypersampsonone B (5) and epi-isohypersampsonone B (6), white amorphous powders. $[\alpha]_{\mathrm{D}}=+60.0^{\circ}(c=0.01, \mathrm{MeOH})$; $\mathrm{UV}(\mathrm{MeOH}) \lambda_{\max } \mathrm{nm}(\log \varepsilon): 245$ (4.32); $\operatorname{ECD}\left(c 1.79 \times 10^{-4} \mathrm{M}\right.$, $\mathrm{MeOH}) \lambda(\Delta \varepsilon): 224(+16.0), 246(+21.46), 290(-7.81) ;{ }^{1} \mathrm{H}-$ and ${ }^{13} \mathrm{C}-\mathrm{NMR}$ see Tables 2 and 3; HR-ESI-MS $m / z: 561.32141[\mathrm{M}+\mathrm{H}]^{+}$ (calcd for $\mathrm{C}_{35} \mathrm{H}_{45} \mathrm{O}_{6}^{+}$: 561.32107).

Isohypersampsonone $\mathrm{C}(7)$, white amorphous powder. $[\alpha]_{\mathrm{D}}=$ $+81.7^{\circ}(c=0.02, \mathrm{MeOH}) ; \mathrm{UV}(\mathrm{MeOH}) \lambda_{\max } \mathrm{nm}(\log \varepsilon): 215$ (3.90), 245 (4.03); $\operatorname{ECD}\left(c 3.24 \times 10^{-4} \mathrm{M}, \mathrm{MeOH}\right) \lambda(\Delta \varepsilon): 209(+22.01)$, 255 (-7.96), $289(+3.90), 319(-0.48) ;{ }^{1} \mathrm{H}$ - and ${ }^{13} \mathrm{C}-\mathrm{NMR}$ see Tables 2 and 3; HR-ESI-MS $m / z: 619.36310[\mathrm{M}+\mathrm{H}]^{+}$(calcd for $\mathrm{C}_{38} \mathrm{H}_{51} \mathrm{O}_{7}^{+}$: 619.36293).
Isohyperisampsin $\mathrm{O}(\mathbf{8})$, white amorphous powder. $[\alpha]_{\mathrm{D}}=$ $+22.4^{\circ}(c=0.06, \mathrm{MeOH}) ; \mathrm{UV}(\mathrm{MeOH}) \lambda_{\max } \mathrm{nm}(\log \varepsilon): 240$ (3.60); $\operatorname{ECD}\left(c 9.46 \times 10^{-4} \mathrm{M}, \mathrm{MeOH}\right) \lambda(\Delta \varepsilon): 221(+4.99), 243(-3.20), 261$ $(+1.24) ; 319(-2.46) ;{ }^{1} \mathrm{H}$ - and ${ }^{13} \mathrm{C}-\mathrm{NMR}$ see Tables 2 and 3 ; HR-ESIMS $m / z: 635.35791[\mathrm{M}+\mathrm{H}]^{+}$(calcd for $\mathrm{C}_{38} \mathrm{H}_{51} \mathrm{O}_{8}{ }^{+}$: 635.35784).

Garcimultinone B (9), white amorphous powder. $[\alpha]_{\mathrm{D}}=+28.3^{\circ}$ $(c=0.04, \mathrm{MeOH}) ; \mathrm{UV}(\mathrm{MeOH}) \lambda_{\max } \mathrm{nm}(\log \varepsilon): 210$ (3.52), 245 (3.57); $\operatorname{ECD}\left(c 6.94 \times 10^{-4} \mathrm{M}, \mathrm{MeOH}\right) \lambda(\Delta \varepsilon): 222(+2.34), 241(-0.89), 255$ (+1.63), $313(-1.15) ;{ }^{1} \mathrm{H}$ - and ${ }^{13} \mathrm{C}-\mathrm{NMR}$ see Tables 2 and 3; HR-ESIMS $m / z: 577.31610[\mathrm{M}+\mathrm{H}]^{+}$(calcd for $\mathrm{C}_{35} \mathrm{H}_{45} \mathrm{O}_{7}^{+}$: 577.31598).

\subsection{Cytotoxicity assay}

Cytotoxicity was measured by the CCK- 8 method.${ }^{16}$ In short, $5 \times$ $10^{3}$ three human tumor cell lines (SGC-7901, HepG2, HCT-116) per well (in $100 \mu \mathrm{L}$ of culture medium) were seeded in 96-well plates. Cells were incubated with five concentrations $(20 \mu \mathrm{M}, 10$ $\mu \mathrm{M}, 5 \mu \mathrm{M}, 2.5 \mu \mathrm{M}$ and $1.25 \mu \mathrm{M}$ ) of each compound in triplicate at $37{ }^{\circ} \mathrm{C}$ for $24 \mathrm{~h}$, and cisplatin was used as a positive control. Then, the cell culture medium was taken out and $100 \mu \mathrm{L}$ cell culture medium containing $10 \%$ CCK- 8 solution was added to per well for $1 \mathrm{~h}$. The absorbance values of each well at $450 \mathrm{~nm}$ were measured using a microplate spectrophotometer. The $\mathrm{IC}_{50}$ values were calculated by the Logit method. ${ }^{17}$

\subsection{NO production measurement and cell viability assay}

The Griess reaction ${ }^{18}$ was used to measure both the accumulation of nitrite in the culture supernatants and the NO synthase 
Table $3{ }^{13} \mathrm{C}$-NMR spectroscopic data of compounds 1 in $\mathrm{CD}_{3} \mathrm{OD}$ and $2-9$ in $\mathrm{CDCl}_{3}(\delta$ in ppm)

\begin{tabular}{|c|c|c|c|c|c|c|c|c|c|}
\hline No. & 1 & 2 & 3 & 4 & 5 & 6 & 7 & 8 & 9 \\
\hline 1 & $83.7 \mathrm{C}$ & $82.7 \mathrm{C}$ & $82.4 \mathrm{C}$ & $82.1 \mathrm{C}$ & $81.5 \mathrm{C}$ & $82.0 \mathrm{C}$ & $82.6 \mathrm{C}$ & $82.3 \mathrm{C}$ & $82.2 \mathrm{C}$ \\
\hline 2 & $203.0 \mathrm{C}$ & $198.8 \mathrm{C}$ & $206.6 \mathrm{C}$ & $205.3 \mathrm{C}$ & $207.5 \mathrm{C}$ & $207.7 \mathrm{C}$ & $203.5 \mathrm{C}$ & $209.0 \mathrm{C}$ & $208.4 \mathrm{C}$ \\
\hline 3 & $74.3 \mathrm{C}$ & $78.3 \mathrm{C}$ & $72.1 \mathrm{C}$ & $74.7 \mathrm{C}$ & $67.6 \mathrm{C}$ & $70.4 \mathrm{C}$ & $76.3 \mathrm{C}$ & $65.9 \mathrm{C}$ & $66.6 \mathrm{C}$ \\
\hline 4 & $204.4 \mathrm{C}$ & $202.6 \mathrm{C}$ & $206.4 \mathrm{C}$ & $208.3 \mathrm{C}$ & $115.6 \mathrm{C}$ & $118.1 \mathrm{C}$ & $106.5 \mathrm{C}$ & $205.9 \mathrm{C}$ & $205.4 \mathrm{C}$ \\
\hline 5 & $69.7 \mathrm{C}$ & $68.2 \mathrm{C}$ & $66.9 \mathrm{C}$ & $66.3 \mathrm{C}$ & $57.5 \mathrm{C}$ & $57.8 \mathrm{C}$ & $57.5 \mathrm{C}$ & $67.5 \mathrm{C}$ & $67.1 \mathrm{C}$ \\
\hline 6 & $44.9 \mathrm{CH}_{2}$ & $38.6 \mathrm{CH}_{2}$ & $48.0 \mathrm{CH}_{2}$ & $48.8 \mathrm{CH}_{2}$ & $30.8 \mathrm{CH}_{2}$ & $30.7 \mathrm{CH}_{2}$ & $40.6 \mathrm{CH}_{2}$ & $45.2 \mathrm{CH}_{2}$ & $47.0 \mathrm{CH}_{2}$ \\
\hline 7 & $47.1 \mathrm{CH}$ & $44.4 \mathrm{CH}$ & $43.6 \mathrm{CH}$ & $43.6 \mathrm{CH}$ & $43.8 \mathrm{CH}$ & $43.7 \mathrm{CH}$ & $44.6 \mathrm{CH}$ & $44.8 \mathrm{CH}$ & $44.5 \mathrm{CH}$ \\
\hline 8 & $56.7 \mathrm{C}$ & $57.8 \mathrm{C}$ & $52.0 \mathrm{C}$ & $52.6 \mathrm{C}$ & $48.0 \mathrm{C}$ & $48.2 \mathrm{C}$ & $52.0 \mathrm{C}$ & $50.9 \mathrm{C}$ & $51.3 \mathrm{C}$ \\
\hline 9 & $203.7 \mathrm{C}$ & $201.9 \mathrm{C}$ & $204.5 \mathrm{C}$ & $204.0 \mathrm{C}$ & $208.6 \mathrm{C}$ & $208.9 \mathrm{C}$ & $208.0 \mathrm{C}$ & $204.1 \mathrm{C}$ & $203.9 \mathrm{C}$ \\
\hline 10 & $194.6 \mathrm{C}$ & $193.4 \mathrm{C}$ & $194.0 \mathrm{C}$ & $193.5 \mathrm{C}$ & $194.7 \mathrm{C}$ & $194.6 \mathrm{C}$ & $194.7 \mathrm{C}$ & $192.6 \mathrm{C}$ & $192.6 \mathrm{C}$ \\
\hline 11 & $136.4 \mathrm{C}$ & $135.3 \mathrm{C}$ & $136.3 \mathrm{C}$ & $136.1 \mathrm{C}$ & $135.9 \mathrm{C}$ & $136.9 \mathrm{C}$ & $137.1 \mathrm{C}$ & $135.3 \mathrm{C}$ & $135.2 \mathrm{C}$ \\
\hline 12 & $130.7 \mathrm{CH}$ & $129.2 \mathrm{CH}$ & $129.3 \mathrm{CH}$ & $129.4 \mathrm{CH}$ & $129.5 \mathrm{CH}$ & $128.6 \mathrm{CH}$ & $129.7 \mathrm{CH}$ & $129.1 \mathrm{CH}$ & $129.2 \mathrm{CH}$ \\
\hline 13 & $129.1 \mathrm{CH}$ & $128.2 \mathrm{CH}$ & $128.0 \mathrm{CH}$ & $128.0 \mathrm{CH}$ & $128.6 \mathrm{CH}$ & $128.2 \mathrm{CH}$ & $127.9 \mathrm{CH}$ & $128.1 \mathrm{CH}$ & $128.3 \mathrm{CH}$ \\
\hline 14 & $133.7 \mathrm{CH}$ & $132.6 \mathrm{CH}$ & $132.0 \mathrm{CH}$ & $132.2 \mathrm{CH}$ & $132.4 \mathrm{CH}$ & $132.3 \mathrm{CH}$ & $132.0 \mathrm{CH}$ & $132.5 \mathrm{CH}$ & $132.5 \mathrm{CH}$ \\
\hline 15 & $129.1 \mathrm{CH}$ & $128.2 \mathrm{CH}$ & $128.0 \mathrm{CH}$ & $128.0 \mathrm{CH}$ & $128.6 \mathrm{CH}$ & $128.2 \mathrm{CH}$ & $127.9 \mathrm{CH}$ & $128.1 \mathrm{CH}$ & $128.3 \mathrm{CH}$ \\
\hline 16 & $130.7 \mathrm{CH}$ & $129.2 \mathrm{CH}$ & $129.3 \mathrm{CH}$ & $129.4 \mathrm{CH}$ & $129.5 \mathrm{CH}$ & $128.6 \mathrm{CH}$ & $129.7 \mathrm{CH}$ & $129.1 \mathrm{CH}$ & $129.2 \mathrm{CH}$ \\
\hline 17 & $28.1 \mathrm{CH}_{2}$ & $23.8 \mathrm{CH}_{2}$ & $32.2 \mathrm{CH}_{2}$ & $38.7 \mathrm{CH}_{2}$ & $46.0 \mathrm{CH}_{2}$ & $45.6 \mathrm{CH}_{2}$ & $83.3 \mathrm{CH}$ & $31.5 \mathrm{CH}$ & $37.8 \mathrm{CH}$ \\
\hline 18 & $120.7 \mathrm{CH}$ & $52.3 \mathrm{CH}$ & $60.1 \mathrm{CH}$ & $82.0 \mathrm{CH}$ & $98.7 \mathrm{CH}$ & $100.0 \mathrm{CH}$ & $88.7 \mathrm{CH}$ & $85.9 \mathrm{CH}$ & $99.8 \mathrm{CH}$ \\
\hline 19 & $135.6 \mathrm{C}$ & $81.9 \mathrm{C}$ & $73.2 \mathrm{C}$ & & & & $70.0 \mathrm{C}$ & $84.3 \mathrm{C}$ & \\
\hline 20 & $18.5 \mathrm{CH}_{3}$ & $29.1 \mathrm{CH}_{3}$ & $31.3 \mathrm{CH}_{3}$ & & & & $27.4 \mathrm{CH}_{3}$ & $21.8 \mathrm{CH}_{3}$ & \\
\hline 21 & $26.1 \mathrm{CH}_{3}$ & $33.1 \mathrm{CH}_{3}$ & $30.5 \mathrm{CH}_{3}$ & & & & $26.4 \mathrm{CH}_{3}$ & $21.4 \mathrm{CH}_{3}$ & \\
\hline 22 & $34.0 \mathrm{CH}_{2}$ & $31.5 \mathrm{CH}_{2}$ & $35.8 \mathrm{CH}_{2}$ & $35.9 \mathrm{CH}_{2}$ & $34.7 \mathrm{CH}_{2}$ & $34.8 \mathrm{CH}_{2}$ & $35.1 \mathrm{CH}_{2}$ & $34.8 \mathrm{CH}_{2}$ & $35.2 \mathrm{CH}_{2}$ \\
\hline 23 & $44.7 \mathrm{CH}$ & $43.4 \mathrm{CH}$ & $43.3 \mathrm{CH}$ & $43.3 \mathrm{CH}$ & $43.4 \mathrm{CH}$ & $43.4 \mathrm{CH}$ & $43.2 \mathrm{CH}$ & $43.6 \mathrm{CH}$ & $43.6 \mathrm{CH}$ \\
\hline 24 & $150.2 \mathrm{C}$ & $149.1 \mathrm{C}$ & $149.1 \mathrm{C}$ & $149.2 \mathrm{C}$ & $149.4 \mathrm{C}$ & $149.5 \mathrm{C}$ & $150.4 \mathrm{C}$ & $149.0 \mathrm{C}$ & $148.8 \mathrm{C}$ \\
\hline 25 & $18.6 \mathrm{CH}_{3}$ & $18.5 \mathrm{CH}_{3}$ & $18.0 \mathrm{CH}_{3}$ & $17.9 \mathrm{CH}_{3}$ & $19.7 \mathrm{CH}_{3}$ & $19.8 \mathrm{CH}_{3}$ & $19.3 \mathrm{CH}_{3}$ & $18.2 \mathrm{CH}_{3}$ & $18.0 \mathrm{CH}_{3}$ \\
\hline 26 & $113.5 \mathrm{CH}_{2}$ & $112.3 \mathrm{CH}_{2}$ & $112.8 \mathrm{CH}_{2}$ & $112.9 \mathrm{CH}_{2}$ & $111.6 \mathrm{CH}_{2}$ & $111.5 \mathrm{CH}_{2}$ & $112.2 \mathrm{CH}_{2}$ & $112.7 \mathrm{CH}_{2}$ & $113.1 \mathrm{CH}_{2}$ \\
\hline 27 & $34.7 \mathrm{CH}_{2}$ & $34.0 \mathrm{CH}_{2}$ & $33.1 \mathrm{CH}_{2}$ & $32.9 \mathrm{CH}_{2}$ & $30.9 \mathrm{CH}_{2}$ & $30.9 \mathrm{CH}_{2}$ & $31.9 \mathrm{CH}_{2}$ & $33.6 \mathrm{CH}_{2}$ & $33.4 \mathrm{CH}_{2}$ \\
\hline 28 & $124.3 \mathrm{CH}$ & $122.6 \mathrm{CH}$ & $122.9 \mathrm{CH}$ & $122.7 \mathrm{CH}$ & $122.8 \mathrm{CH}$ & $122.8 \mathrm{CH}$ & $123.2 \mathrm{CH}$ & $122.7 \mathrm{CH}$ & $122.7 \mathrm{CH}$ \\
\hline 29 & $133.2 \mathrm{C}$ & $132.5 \mathrm{C}$ & $132.2 \mathrm{C}$ & $132.4 \mathrm{C}$ & $132.1 \mathrm{C}$ & $132.1 \mathrm{C}$ & $132.3 \mathrm{C}$ & $132.4 \mathrm{C}$ & $132.4 \mathrm{C}$ \\
\hline 30 & $18.3 \mathrm{CH}_{3}$ & $18.2 \mathrm{CH}_{3}$ & $18.2 \mathrm{CH}_{3}$ & $18.2 \mathrm{CH}_{3}$ & $18.2 \mathrm{CH}_{3}$ & $18.2 \mathrm{CH}_{3}$ & $18.2 \mathrm{CH}_{3}$ & $18.2 \mathrm{CH}_{3}$ & $18.2 \mathrm{CH}_{3}$ \\
\hline 31 & $26.6 \mathrm{CH}_{3}$ & $25.9 \mathrm{CH}_{3}$ & $26.0 \mathrm{CH}_{3}$ & $26.0 \mathrm{CH}_{3}$ & $25.9 \mathrm{CH}_{3}$ & $25.9 \mathrm{CH}_{3}$ & $25.9 \mathrm{CH}_{3}$ & $26.0 \mathrm{CH}_{3}$ & $26.0 \mathrm{CH}_{3}$ \\
\hline 32 & $57.9 \mathrm{CH}$ & $59.0 \mathrm{CH}$ & $28.2 \mathrm{CH}_{2}$ & $28.4 \mathrm{CH}_{2}$ & $25.3 \mathrm{CH}_{2}$ & $25.3 \mathrm{CH}_{2}$ & $29.1 \mathrm{CH}_{2}$ & $31.7 \mathrm{CH}_{2}$ & $32.0 \mathrm{CH}_{2}$ \\
\hline 33 & $62.8 \mathrm{CH}$ & $56.3 \mathrm{CH}$ & $57.9 \mathrm{CH}$ & $53.2 \mathrm{CH}$ & $49.6 \mathrm{CH}$ & $48.9 \mathrm{CH}$ & $50.1 \mathrm{CH}$ & $42.3 \mathrm{CH}$ & $41.8 \mathrm{CH}$ \\
\hline 34 & $58.9 \mathrm{C}$ & $79.4 \mathrm{C}$ & $47.2 \mathrm{C}$ & $49.8 \mathrm{C}$ & $86.5 \mathrm{C}$ & $86.2 \mathrm{C}$ & $86.4 \mathrm{C}$ & $88.8 \mathrm{C}$ & $88.0 \mathrm{C}$ \\
\hline 35 & $19.3 \mathrm{CH}_{3}$ & $26.3 \mathrm{CH}_{3}$ & $30.8 \mathrm{CH}_{3}$ & $23.2 \mathrm{CH}_{3}$ & $30.6 \mathrm{CH}_{3}$ & $32.2 \mathrm{CH}_{3}$ & $31.5 \mathrm{CH}_{3}$ & $28.9 \mathrm{CH}_{3}$ & $29.4 \mathrm{CH}_{3}$ \\
\hline 36 & $25.1 \mathrm{CH}_{3}$ & $32.0 \mathrm{CH}_{3}$ & $16.2 \mathrm{CH}_{3}$ & $19.2 \mathrm{CH}_{3}$ & $28.0 \mathrm{CH}_{3}$ & $28.8 \mathrm{CH}_{3}$ & $24.3 \mathrm{CH}_{3}$ & $18.2 \mathrm{CH}_{3}$ & $18.1 \mathrm{CH}_{3}$ \\
\hline 37 & $23.0 \mathrm{CH}_{3}$ & $23.5 \mathrm{CH}_{3}$ & $23.1 \mathrm{CH}_{3}$ & $23.0 \mathrm{CH}_{3}$ & $22.6 \mathrm{CH}_{3}$ & $22.5 \mathrm{CH}_{3}$ & $23.1 \mathrm{CH}_{3}$ & $22.8 \mathrm{CH}_{3}$ & $22.9 \mathrm{CH}_{3}$ \\
\hline 38 & $23.5 \mathrm{CH}_{3}$ & $23.9 \mathrm{CH}_{3}$ & $26.7 \mathrm{CH}_{3}$ & $27.1 \mathrm{CH}_{3}$ & $25.4 \mathrm{CH}_{3}$ & $25.3 \mathrm{CH}_{3}$ & $27.0 \mathrm{CH}_{3}$ & $25.4 \mathrm{CH}_{3}$ & $25.5 \mathrm{CH}_{3}$ \\
\hline
\end{tabular}

activity. The viability of the microglial cells was evaluated by the CCK-8 method.

\section{Conclusions}

The phytochemical study of the fruits of $G$. multiflora led to the isolation of nine new caged PPAPs, including adamantane type PPAPs (1-2), and homoadamantane type PPAPs (3-9). A new epimeric pair of isohypersampsonone $B$ (5) and epiisohypersampsonone $\mathrm{B}$ (6) with an unusual hexahydrofuro $[2,3-b]$ furan-diepoxy ring system were not separated due to the rapid equilibration between the two isomeric forms. Cytotoxicities of all isolated compounds against three human cancer cell lines (SGC-7901, HepG2, HCT-116) by CCK-8 method and the nitric oxide production inhibitory activity of lipopolysaccharides-stimulated RAW 264.7 cells were evaluated. Compounds 8 and 12 displayed mild cytotoxicity against three human cancer cell lines and moderate NO inhibitory effects on LPS-induced macrophages. These results indicated that $G$. multiflora fruits are new rich sources of caged PPAPs with structural diversity.

\section{Conflicts of interest}

There are no conflicts to declare.

\section{Acknowledgements}

This work was financially supported by the National Natural Science Foundation of China (31370379), the National Major New Drugs Innovation and Development (2017ZX09301060), the Special Fund for Basic Scientific Research of Central Colleges, South-Central University for Nationalities (CZP18004) and Hubei Provincial Technical Innovation Program (2017AHB067).

\section{References}

1 L. D. C. Brito, A. L. R. Berenger and M. R. Figueiredo, Food Chem. Toxicol., 2017, 109, 847-862. 
2 C. Q. Liu, P. C. Ho, F. C. Wong, G. Sethi, L. Z. Wang and B. C. Goh, Cancer Lett., 2015, 362, 8-14.

3 S. Baggett, P. Protiva, E. P. Mazzola, H. Yang, E. T. Ressler, M. J. Basile, I. B. Weinstein and E. J. Kennelly, J. Nat. Prod., 2005, 68, 354-360.

4 X. W. Yang, R. B. Grossman, E. P. Mazzola and G. Xu, Chem. Rev., 2018, 118, 3508-3558.

5 B. Liu, X. B. Zhang, R. W. Bussmann, R. H. Hart, P. Li, Y. J. Bai and C. L. Long, Econ. Bot., 2017, 70, 416-430.

6 C. W. Ting, T. L. Hwang, I. S. Chen, M. H. Yen and J. J. Chen, Chem. Biodiversity, 2012, 9, 99-105.

7 J. J. Chen, C. W. Ting, T. L. Hwang and I. S. Chen, J. Nat. Prod., 2009, 72, 253-258.

8 C. W. Ting, T. L. Hwang, I. S. Chen, M. J. Cheng, P. J. Sung and J. J. Chen, Chem. Biodiversity, 2014, 11, 819-824.

9 Y. Ye, X. W. Yang and G. Xu, Tetrahedron, 2016, 72, 30573062.

10 H. C. Zhu, C. M. Chen, J. Yang, X. N. Li, J. J. Liu, B. Sun, S. X. Huang, D. Y. Li, G. M. Yao, Z. W. Luo, Y. Li,
J. W. Zhang, Y. B. Xue and Y. H. Zhang, Org. Lett., 2014, 16, 6322-6325.

11 J. S. Zhang, Y. H. Zou, Y. Q. Guo, Z. Z. Li, G. H. Tang and S. Yin, $R S C A d v .$, 2016, 6, 53469-53476.

12 H. C. Zhu, C. M. Chen, J. W. Zhang, Y. Guo, D. D. Tan, G. Z. Wei, G. Yang, J. P. Wang, Z. W. Luo, Y. B. Xue and Y. H. Zhang, Chin. Chem. Lett., 2017, 28, 986-990.

13 G. D. Chen, G. K. Xiao, X. S. Yao and H. Gao, Journal of International Pharmaceutical Research, 2015, 42, 738-743.

14 L. H. Hu and K. Y. Sim, Tetrahedron Lett., 1998, 39, 79998002.

15 X. W. Yang, M. M. Li, X. Liu, D. Ferreira, Y. Ding, J. J. Zhang, Y. Liao, H. B. Qin and G. Xu, J. Nat. Prod., 2015, 78, 885-895.

16 J. T. Zhang, X. Li, X. Y. Wang, L. L. Mu, M. M. Yuan, B. K. Liu and H. Z. Shi, J. Hazard. Mater., 2018, 359, 1-8.

17 W. S. Xiang, J. D. Wang, X. J. Wang and J. Zhang, J. Antibiot., 2009, 62, 229-231.

18 G. Y. Cao, X. W. Yang, W. Xu and F. Li, Food Chem. Toxicol., 2013, 62, 167-171. 